The Abandoned Ones: Non-Status Indians and Political Organizing

David R. Newhouse

Business Administration Chair, Indigenous Studies, Trent University

Yale D. Belanger

Political Science Department, University of Lethbridge

Pamela Ouart

PhD Candidate, Trent University

aboriginal policy studies Vol. 3, no. 3, 2014, pp. 4-26

This article can be found at:

http://ejournals.library.ualberta.ca/index.php/aps/article/view/22226

ISSN: 1923-3299

Article DOI: http://dx.doi.org/10.5663/aps.v3i3.22226

aboriginal policy studies is an online, peer-reviewed and multidisciplinary journal that publishes original, scholarly, and policy-relevant research on issues relevant to Métis, non-status Indians and urban Aboriginal people in Canada. For more information, please contact us at apsjournal@ualberta.ca or visit our website at www.ualberta.ca/nativestudies/aps/. 


\title{
The Abandoned Ones: Non-Status Indians and Political Organizing
}

\author{
David R. Newhouse \\ Business Administration Chair, Indigenous Studies, Trent University \\ Yale D. Belanger \\ Political Science Department, University of Lethbridge \\ Pamela Ouart \\ PhD Candidate, Trent University
}

\begin{abstract}
This article explores contemporary issues facing Non-Status Indians in Canada, and their struggles to politically organize in particular. Using James Scott's theoretical position that political states attempt to create legible populations in order to administer them more easily, this article examines the category of "Non-Status Indians" and the impacts of federal policy making on their ability to organize. The National Indian Council (NIC), established in 1961, originally articulated the concept of Non-Status Indians as a category of Aboriginal people. Internal pressures led the NIC to split into two groups in 1968: the National Indian Brotherhood, representing status and Treaty Indians; and the Native Council of Canada (NCC), representing Métis and Non-Status Indians. A second severance occurred in 1983 when the Métis National Council split from the NCC, after which the Council for Aboriginal Peoples (CAP) emerged to represent Non-Status Indians and urban Aboriginal peoples. During this period, public policy makers, Status Indians, and Métis literally abandoned the Non-Status label. During the opening decade of the twenty-first century, Non-Status Indian organizations have emerged as new players on the Aboriginal policy landscape. This article explores this phenomenon, based upon key informant interviews with Non-Status Indian leaders conducted specifically for this project.
\end{abstract}

The Non-Status Indians truly became the forgotten people. Even supposedly informed status Indian leaders assumed that their brothers and sisters have done something wrong to find themselves in their excluded position. Instead of experiencing the "privilege" of enfranchisement, Non-Status Indian people found themselves totally disfranchised from almost all tribal or band functions.

Bill Wilson $(1985,64)$

aboriginal policy studies, vol. 3, no. 3, 2014

www.ualberta.ca/nativestudies/aps/

ISSN: 1923-3299 


\section{Introduction}

The contemporary Aboriginal ${ }^{1}$ political scene has come to be dominated by intense debates about representation based upon state-sanctioned identities: Status Indians, Métis, Inuit, Urban, and Treaty, among others. To date, this primary focus on identity tends to overshadow the surprising and discreet emergence of a new set of representational organizations, built around an identity category, that have been described as "administrative rather than 'real."'2 Specifically, we mean the identity category of "Non-Status Indian," a category of Indian person that the pre-1960s set of Aboriginal representational organizations claimed to represent and subsequently abandoned during the split between Metis and Indian, now First Nation, representation; and the term's early twenty-first century reemergence, symbolized by the arrival of a set of Non-Status Indian organizations.

Max Forte (2013), Bonita Lawrence (2004), and Pam Palmater (2013) efficiently explore the politics of identity, at both the individual and collective level (i.e., nation, community), resulting from the state definitions of Aboriginality. We contend that concentrating on post-contact, state-imposed identity markers in this way obscures ongoing Aboriginal political attempts at preserving what James Tully (1995) has described as "learning the art of mutual recognition," a cross-cultural practice dating to contact that fostered peaceful working relationships between political contemporaries living side-by-side-in this case, Aboriginal and colonial leaders. When two sides meet, the goal, as highlighted by Jeremy Waldron $(2000,155)$, is ostensibly to "come to terms with one another, and set up, maintain, and operate the legal frameworks that [are] necessary to secure peace, resolve conflicts, do justice, avoid great harms, and provide some basis for improving the condition of life." This practice can lead to mutual recognition, which "is to emerge from anonymity, to be seen and acknowledged for what you are," concluded Michael Ignatieff (2000, 86-87), while adding that groups seek recognition to have both "their equality recognized" and "their differences acknowledged" (see also Taylor 1993). Albeit the political norm for the first 150 years of contact, Canadian colonial officials had, as of the 1850s, formally abandoned

1 The term "Aboriginal peoples" indicates any one of the three constitutionally defined groups that form what is known as Aboriginal peoples in Canada (Métis, Inuit, and Indian) and who self-identify as such. The term "First Nation" is used here to denote a reserve community or Indian band. The term "Indian," as used in legislation or policy, will also appear in discussions concerning such legislation or policy. The term "Indigenous" here does not represent a legal category. Rather, it is used to describe the descendants of groups present in a territory at the time when other groups of different cultures or ethnic origin arrived there, and who identify as such. Statistics Canada measures Aboriginality in four different ways and, most importantly, distinguish between Aboriginal ancestry and Aboriginal identity. Aboriginal ancestry measures Aboriginality through a self-declaration of Aboriginal ancestry, whereas Aboriginal identity asks individuals if they selfidentify as Aboriginal (whether First Nations, Métis, or Inuit). Moreover, individuals are given the option of identifying with more than one category (e.g., one might declare oneself both First Nations and Métis). For the purposes of this study, "Aboriginal" refers to those who self-identify as Aboriginal (whether First Nations, Métis, or Inuit) and only those who choose a single category.

2 Chris Andersen, Aboriginal Policy Forum, Congress of Social Sciences and Humanities, Montreal, 1 June 2010. 
political recognition of Indians in lieu of developing state criteria that categorized Indians into two groups: legal (Status) and non-legal (Non-Status), for ease of bureaucratic management. This management based on identity has, according to Lawrence $(2004,7)$, "primarily been shaped by a system of regulation and control" that has led to Aboriginal dispossession from territories, detachment from traditional identities, physical diaspora, social marginalization, and lost political influence.

Lost in this identity dialogue is any concerted examination of how historic political processes predicated upon the idea of mutually beneficial political interfaces continue to inform Aboriginal political organizing and, specifically, Non-Status Indian organizing. Similar to the early Aboriginal political organizers of the 1870s (and after), who encouraged Canada's leaders to restore what we describe as "the convention of recognition" through the re-affirmation of historic political, economic, and social relationships, modern Non-Status Indian leaders likewise propose to establish analogous relationships. Aboriginal political organizing is not the only, or by any means the most successful, approach to re-establishing political relationships, as evidenced by its judicious critics (e.g., Alfred 2009; Ladner 2003). It was, all the same, a popular strategy, as confirmed by the twenty-four Aboriginal political organizations to emerge between 1870 and 1946, and the dozens if not hundreds that materialized afterwards seeking to advance Aboriginal political goals and stem the loss of political influence attributable to federal Indian legislation and its attendant policies. Primarily younger men educated in English and Canadian political traditions, the leaders of most of these organizations had witnessed first-hand, as of the twentieth century's opening decade, the Crown's enthusiasm for legislating on behalf of Indians, which was framed as a form of inter-cultural political engagement (Belanger 2006). To Canadian leaders, the level of associated organizational activity generated apprehension. In an effort to stymie these efforts, the Indian Act was amended in 1927 to deter Indians from hiring lawyers and gathering in groups, effectively restricting political organizing (Titley 1986). The limitations did not dissuade Aboriginal leaders, who referenced traditional political philosophies that favoured relationship building and ongoing dialogue, and then created additional and more powerful organizations into the 1940s and beyond (Belanger 2006). In most cases, the goals of Aboriginal political institutions have been broadly conceived as directed towards solving the Canada Problem (Newhouse and Belanger 2010), a complex set of goals involving the convention of recognition and quality of life improvements.

The Crown's desire to simplify its political interface with Aboriginal peoples played into these organizations' growing popularity: instead of dealing with a wide variety of First Nations, Métis, and Inuit organizations and leaders, federal officials now had the luxury of working with a handful of leaders (Belanger 2006). One could argue that these organizations were little more than reactive, anti-colonial agents, rather than organic Indigenous political bodies anchored by historic political philosophies and ideologies. Closer scrutiny, however, reveals that Aboriginal organizing was informed by historic organizing models that integrated non-Aboriginal operational elements and were, all the same, intent on safeguarding local economies and landholdings (Belanger 2006). By 1946, 
these organizations had evolved to where Aboriginal leaders were invited to Ottawa to participate in a Special Joint Committee of Parliament and the Senate. There, they spoke with federal officials and presented their concerns about Indian affairs administration, and about federal policies and laws (Kulchyski 1993; Leslie 1999; Shewell 2004). This, to many Aboriginal leaders in attendance, signalled federal efforts at a return to the abandoned convention of recognition. Little came of this effort and, in subsequent decades, federal officials attempted to further simplify the Federal-First Nations organizational interface. Increasingly frustrated with the lack of federal response in 1968, the National Indian Brotherhood (NIB) surfaced as Canada's national Aboriginal organization (McFarlane 1993; Manuel and Posluns 1974).

Despite its existence as a visible category of Aboriginal person, existing Aboriginal political organizations in the late 1960s started abandoning Non-Status Indians due in part to the fact that federal officials had identified Status Indians as Canada's "legitimate Indians" in both policy and law. This influenced Non-Status access to federal programming, further driving a wedge between Status and Non-Status Indians, ${ }^{3}$ and led to political marginalization that made it seem as though Non-Status Indians had withdrawn from the political landscape. It is expected that attempts at Non-Status political organizing and representation occurred, ${ }^{4}$ but we know little about the historical timelines and allied groups, even though the emergence of contemporary political organizations (e.g., Kawartha Nishnawbe First Nation, Qalikpu Mi'kmag First Nation Band) provides us with a sense of their political goals and the roles they anticipate playing in Non-Status Indians' lives.

Based on this brief overview, the rules regarding eligibility for legal Indian status as defined through the Indian Act are the primary source of these tensions, and as James Scott (1998) would suggest, they were intentionally implemented to create legible populations if Canada was to govern more effectively. Over time, through state policy and with state assistance, Indians as a legal category of person were expected to disappear. Indians, however, did not disappear, and the legislation and jurisprudence that effectively split a state-constructed rights-bearing community (Status Indians) from that of a non-rightsbearing community (Non-Status Indians) continues to restrict Non-Status Indian access to funding set aside for Status Indians. The federal policies and their application, which continue to privilege Status Indians, amplify tensions concerning fairness of interpretation, inclusion, access to services, and identities, both cultural and legal. As such, the Aboriginal political and social landscape, instead of becoming more legible and comprehensible, has become more internally complex and nuanced, particularly after Non-Status Indians started to organize to advance their interests and secure access to government resources to meet their needs. This issue is timely, considering the Non-Status Indian community's growth.

3 In recent years, Non-Status Indians have benefitted from general spending intended to help urban Aboriginal peoples.

4 Non-Status Indians were not entirely abandoned by the federal government, as it created the Federal Interlocutor for Metis and Non-Status Indians in 1985. The mandate of this federal cabinet portfolio was to liaise with Non-Status Indian representative organizations. 
In 2006, the Non-Status Indian population was 133,155, representing approximately 11 percent of the total Aboriginal population, and is expected to increase 77 percent by the year 2026. The Non-Status Indian population is predominately urban, with about 75 percent living in urban areas. By comparison, the status Indian population of the same period was 673,780, with approximately 52 percent living in urban areas (Canada 2009).

This article attempts to enhance our understanding of why Non-Status Indians organize, the mandates of their organizations, and where they perceive themselves within the larger Aboriginal policy environment. Are these organizations representatives of what might be described as a new political assembly of Aboriginal peoples? What are the political goals of these groups? How do they see themselves in relation to other Aboriginal groups? And who are the members of these new groups? The first section of the article establishes the history leading to the creation of the Non-Status Indian category and the evolution of Aboriginal political organizations in Canada, with an emphasis on Non-Status organizing. The second section offers our interpretation of the empirical data collected during fieldwork that consisted of interviews with Non-Status organization representatives, and those who have worked in this field. It concludes with a discussion of the key trends identified.

\section{Part I: Policy and Literature Overview}

\section{Status/Non-Status Foundations}

In King George III's Royal Proclamation of 1763, Indians in British North America were granted protected status, an inferior legal standing one held until attaining colonial citizenship. Appropriately, losing one's status as an Indian was considered an honour in the eyes of the Crown. Indian as a legal category of person in Canada dates to the introduction of An Act for the Better Protection of the Lands and Property of Indians in Lower Canada and An Act for the Protection of Indians in Upper Canada from imposition, the property occupied or enjoyed by them from trespass and injury, both of which the Province of Canada adopted in 1850 (Leslie and Maguire 1978). The category was sustained in 1857's An Act to Encourage the Gradual Civilization of Indian Tribes in this Province, and to Amend the Laws Relating to Indians, which introduced the concept of "enfranchisement" (the right to vote), and the means by which one could voluntarily give up one's legal status as Indian and become a full British subject. To become civilized in the eyes of the law, Indians had to formally renounce their heritage, as the two categories-Indian and civilized-were mutually exclusive. From this point on, analogous legislation came to be acknowledged as laws of civilization, from which two categories of Indians were established: Status Indians, who would be legally recognized as Indians and as such still in need of funded programs to aid in their transition to civilization; and Non-Status Indians, formerly legal Indians who had attained a suitable level of civilization and no longer required analogous funding.

In 1860, authority for Indians and Indian lands was formally transferred to the Canadian colonial legislature, which embraced a policy of civilization that would continue until Indigenous peoples formally accepted European/colonial norms. Following Canadian 
Confederation in 1867, the pith and substance of the 1857 Gradual Civilization Act was formally codified in the General Enfranchisement Act of 1869 and then the Indian Act of 1876. Each act sequentially reaffirmed the idea of inferior protected Indian status, and the need for Indians to be lifted out this condition to full British citizenship:

Our Indian legislation generally rests on the principle, that the aborigines are to be kept in a condition of tutelage and treated as wards or children of the State.... [T] he true interests of the aborigines and of the State alike require that every effort should be made to aid the Red man in lifting himself out of his condition of tutelage and dependence, and that is clearly our wisdom and our duty, through education and every other means, to prepare him for a higher civilization by encouraging him to assume the privileges and responsibilities of full citizenship (Royal Commission on Aboriginal Peoples [RCAP] 1996, Vol. 1, Chapter 9).

The Indian Act remains a comprehensive and adaptable piece of legislation that has been utilized to regulate literally every aspect of Aboriginallife. ${ }^{5}$ For example, Indian Act provisions enabled Indian agents to pressure community leaders to replace traditional governing practices such as hereditary leadership selection methods with European, municipal-style elected councils. An enfranchisement process was deployed to assist qualified individuals to acquire full citizenship after relinquishing their ties to their community. The Indian Act was, ironically, considered a temporary, stop-gap measure that would outlive its usefulness following Indians' absorption into Canadian society (Dockstator 2001). Since Indians did not disappear and few took advantage of the enfranchisement provisions, the Indian Act remains at the foundation of federal Indian policy, which has proven to be difficult to both repeal and modify, for its effects are interpolated into most aspects of contemporary Aboriginal society.

From an operational perspective, Indians who were registered with the federal government as Indians-i.e., Status Indians, according to the terms of the Indian Actwere eligible to access federal government services until they attained civilization. NonStatus Indians were not registered (for a discussion of the reasons, see Lawrence 2004) and therefore not eligible for comparable federal programs. Clearly, eliminating status, and thus the government's ongoing responsibility for "Indians, and lands reserved for the Indians," was a fundamental policy goal (RCAP 1996). Indians, however, saw some benefit to remaining status, as it enabled them to move ahead with claims to federal resources and policy attention. In choosing to restrict its policy focus, the federal government provided Indian status with a set of characteristics that made it a desirable category for those who were marginalized as a consequence of the same laws.

\section{Non-Status Organizing}

Starting in 1870 and continuing into the twentieth century, Aboriginal leaders formed political organizations on the belief that such organizations could assist their nations with reasserting their desire to participate as partners in Canada's evolution (Belanger 2006).

5 Strictly speaking, the Indian Act applied only to those considered Indians. However its application also affected those who we would now consider part of the category "Aboriginal." 
The most famous pre-1960 examples include the General Indian Council in 1870 (Shields 2001), the Indian Rights Association in 1909 (Galois 1992), the League of Indian Nations in 1919 (Titley 1983; Kulchyski 1988), and the North American Indian Brotherhood in 1944 (Patterson 1962; 1978). During this nine-decade, post-1870 period, dozens of organizations emerged and none distinguished between Status and Non-Status until The National Indian Council (NIC) in 1961. Funded by federal largesse and guided predominantly by prairie Aboriginal leaders, the NIC represented three of Canada's four major Aboriginal groups: Treaty and Status Indians, Non-Status Indians, and the Métis (the Inuit were not involved). No extensive work has been conducted to date exploring the NIC's operations, but its original mandate was to advance "unity among all Indian people," which suggests that the aforesaid legal divisions were relevant community concerns. The NIC acknowledged the variety of regional advocacy groups and larger Indian political organizations, and advocated for both Métis and Non-Status Indians. Unfortunately, the NIC was unable to generate significant political standing with reserve and rural Aboriginal communities, and the grassroots viewed its top-down leadership model with suspicion. The NIC's leaders revealed the complexity in reconciling the interests of all of the various Aboriginal groups nationally, in particular the evident "tensions between treaty Indians, principally from the prairie provinces, and Métis and Non-Status Indians over the strategy to be followed." Specifically, "Indians with treaties preferred to pursue claims on the basis of treaty promises, but those without treaties (both Indians and Métis) found it more attractive to argue from a basis of Aboriginal rights" (Miller 1991, 337).

Similar pressures led the three national Aboriginal groups working under the NIC banner consensually to split in 1968, with the Status and Treaty groups forming the National Indian Brotherhood (NIB). The Non-Status Indians and the Métis remained united and went on to form the Native Council of Canada (NCC) (McFarlane 1993). Whereas the NIB claimed to represent Indians (on-reserve), the NCC was composed of provincial and territorial organizations that were typically called Native councils or Métis and Non-Status Indian associations, which addressed their lack of recognition as Aboriginal peoples while challenging their constituency's exclusion from federal responsibility. An Ottawa-NIB relationship soon flourished that privileged Status Indians (Ponting and Gibbons 1980). Non-Status Indians weren't ignored per se, but as putative assimilated individuals they no longer needed or depended upon government funding-at least from a government perspective. On the ground, political relationships were much more complex, as evidenced by the political union between Métis and Non-Status Indians in the 1960s and 1970s (Sawchuck 2008).

In 1977, for instance, the Métis Association of Alberta's constitution allowed for both Métis and Non-Status Indian members, a political alliance that lasted until the Canadian Constitutional talks of the late 1970s and early 1980s (Sawchuck 1995). Similarly, the Ontario Métis and Non-Status Indian Association, established in 1971, represented both Métis and Non-Status Indians. In 1975 the Association of Métis and Non-Status Indians of Saskatchewan was formed, whereas to the east, the Manitoba Métis Federation to some 
extent represented these multiple interests, even if no specific organization emerged to represent Non-Status Indian interests (Sawchuck 1995). As Bill Wilson (1985) highlighted, the emergence of the British Columbia Association of Non-Status Indians in 1969, and the subsequent creation of the British Columbia Association of Indian Chiefs, was symbolic of the nascent Status-Non-Status organizational divide. The constitutional dialogue of the late 1970s and early 1980s exacerbated this division after Métis sought and obtained recognition as an Aboriginal people. Several Non-Status Indian political organizations surfaced during this politically fractious period, when groups such as the Ontario Métis and Non-Status Association cleaved into individual associations (Sawchuck 2003). Others, such as the Association of Métis and Non-Status Indians of Saskatchewan, dissolved and Saskatchewan Métis came to be represented by the Métis Society of Saskatchewan. It became common for Non-Status Indians seeking representation to gravitate toward becoming members of the Congress of Aboriginal Peoples (CAP), although this was not the norm: for instance, no provincial organization emerged in Manitoba to represent Non-Status interests.

The federal government provided financial resources and assistance where possible to aid with these organizations' operations. The most noteworthy was the Aboriginal Representative Organizational Program (AROP, est. 1971), which provided core funding in support of Aboriginal political organizations' operations, thus ensuring the "development of stable and effective organizational structures capable of interacting with all levels of government and society, and to participate in and effect positive changes to their political, social, cultural, educational and economic lives" (Belanger, Fitzmaurice, and Newhouse 2008, 38). This central mandate was expansive in scope when compared to the NIC's onedimensional political approach to representation, and included programming for Aboriginal women, urban Aboriginal populations through friendship centres, communications, and social and cultural development. This mandate was expanded to include constitutional reform and northern broadcasting, to help improve socio-economic and socio-political conditions of Aboriginal people by providing them with a representative political voice in Canadian policy-making fora, establishing programs promoting Aboriginal culture, connecting communities across the country, and creating and/or enhancing existing community services in urban and rural communities. By the end of the 1970s, AROP programming was well-established, and funded a foundational infrastructure of Aboriginal advocacy and service organizations (Newhouse 2003). With social issues such as training, unemployment, housing, and community services being addressed, albeit not durably, federal and Aboriginal focus shifted to the greater challenges of Aboriginal rights and governance. Once again, Non-Status Indians found their interests ignored in Ottawa.

AROP did, however, inadvertently set into motion the development of Non-Status Indian political organizations. Specifically, as Status Indian organizations were established and subtly integrated into the federal Indian policy regime, Non-Status Indians lacking representation rallied and lobbied Ottawa for appropriate policy changes to offset the aforesaid privileging effect. In other words, Non-Status Indians began to identify their own policy concerns and lobby Ottawa for appropriate programming based on political 
recognition of Non-Status Indians as a category of evolving, rather than disappearing, Indians. Presaging the current political landscape in 1983, the NCC agreed to split formally into the Métis National Council (MNC), representing Métis, and the Congress of Aboriginal Peoples (CAP), representing Non-Status and urban Aboriginal peoples. By the early 1990s, roughly four thousand Aboriginal organizations were operational, a number that included Aboriginal Women's organizations, Aboriginal political organizations, and Friendship Centres (Chapman, Newhouse, and McCaskill 1991). Joe Sawchuck (2003) has written that the developing Aboriginal political landscape prized differentiation over political unity. As an example, during this time, Métis people sought and obtained constitutional recognition as Aboriginal peoples, while the federal government maintained its fixed approach by narrowly to defining its responsibilities for Indians, who in this instance were on-reserve Status Indians. This reinforced the federal conviction that they were Canada's authentic, legitimate Indian community under the Indian Act, and thus solely entitled to federal programming dollars (e.g., Belanger 2013).

In this milieu the slow, albeit consistently evaporating, standing of Non-Status issues from the mandate of most of the national Indian organizations should come as no surprise in what was becoming a financially and politically tenuous environment. Status Indian and Métis political organizations remained politically separated in pursuit of their concerns, whereas Non-Status Indian organizations in various cities nationally adopted similar approaches to promote their own principles and agendas dedicated to advancing their distinctive concerns. Consequently, the Aboriginal population is, according to our reading of Scott's (1998) theoretical framework, legible and, theoretically, more manageable. Status Indian communities remain dependent on federal funding and vulnerable to bureaucratic whims, while Non-Status Indians are compelled to battle federal officials for legal recognition, hoping to secure the attendant funding arrangement. It should be noted that federal officials tend to view Aboriginal organizations as little more than an assortment of special interest groups lacking political teeth.

This simplified overview of the Status-Non-Status divide continues to inform federal and provincial program delivery, although few academics have explored the complex character of Non-Status Indian organization development and their political end games. Non-Status Indians are creating new and distinct political organizations with exclusive agendas directed at securing their legal recognition as Indians, improving federal/provincial funding for community development, and preserving their identities as Indians. The Congress of Aboriginal Peoples currently dominates the Non-Status political landscape, while claiming to represent all off-reserve Aboriginal peoples. As an example, CAP's Ontario affiliate (the Ontario Coalition of Aboriginal People) presents itself as "a Political voice of Métis, Status Métis, Non-Status Indians and Status Indians living off First Nation territories in Ontario" (OCAP 2008). A new political entity, the Non-Status First Nation, has emerged to advocate for Non-Status Indians: the Qualipu Mi'kmaq First Nation Band, for example, formed in Newfoundland in 2008 as a result of an agreement between the Government of Canada and the Federation of Newfoundland Indians to create a landless Mi'kmaq Indian Act band; and 
the Non-Status Indian Saskatchewan River First Nation Band incorporated in $1998 .^{6}$ The Ardoch Algonquin First Nation describes itself as a "confederation of Algonquin families who have lived in the Ottawa River watershed since time immemorial ... and who wish maintain an enduring sense of Algonquin community."

Notably, Sawchuk (1995) describes what has become the norm: the various local, provincial, and federal forces that are at play in this fluid and ever-changing environment have led Non-Status Indians to forge new political relationships in pursuit of their sociopolitical desires. We describe this process as demonstrating an un-willingness to remain abandoned. The remainder of this article presents the perspectives of Non-Status Indian political leaders as they negotiate this complex political environment.

\section{Part II-Non-Status Indian Organizing: A View from the Field}

Historically, Métis and Non-Status Indians had no representative national organizational body that could help address the injustices brought upon them by the Crown through successive acts of discriminatory legislation. Throughout history, Métis and Non-Status Indians had their identities as peoples changed, redefined and then changed again, all at the whim of Parliament in order to reduce, and/or eventually rid itself of the "Indian Problem." The issue of identity is extremely important to everyone, particularly Aboriginal Peoples, as it defines who you are as an individual and a human being.

Research participant July 2, 2013

In an attempt to better understand the evolution of Non-Status political organizations, telephone interviews were conducted from July to November 2012 with nine Non-Status Aboriginal individuals either working with seven Non-Status organizations or who have pursued the study of Canadian policy and its impacts on Non-Status Indians. Our purpose was to obtain an on-the-ground overview of their experiences regarding Canadian policy's impacts on their lives and what is driving their political responses, and to further our understanding of the role policy and Canadian hegemony continue to play in the Status/Non-Status dialogue. The key questions posed to these organizational leaders/ administrators are as follows:

a. What challenges confront Non-Status Indians?

b. What is the purpose/goal of your organization?

c. Describe your political alliances (what groups do you work with) in pursuit of your goals?

d. What is the role of government in addressing Non-Status issues?

6 The Saskatchewan River First Nation describes itself as the only Non-Status Indian Band in Canada. See https://sites.google.com/site/saskatchewanriverfirstnation.

7 For a more in-depth discussion, see http://www.aafna.ca/mission.html. 


\section{Methodology}

A distinctive feature of this study is the inclusion and views of Non-Status Aboriginal peoples. Doing so allows us to obtain an on-the-ground overview of these experiences regarding Canadian policy's impacts on their lives and what is driving their political responses; to locate their experiences within and responses to social dynamics influencing what it means to be a Non-Status Aboriginal person; and to further our understanding of the roles policy and Canadian hegemony continue to play in the Status/Non-Status dialogue. The research's exploratory nature, combined with the fact that we anticipate additional related community-based research, has led us to conclude that one interview with representatives from seven Non-Status political organizational was sufficient for the present study. Two additional interviewees have pursued the study of Canadian policy and its impacts on Non-Status Indians. Following University of Lethbridge ethics approval to conduct research with human subjects, an invitation to participants was personally delivered by telephone, after which a follow-up email was sent and nine individuals were selected for interviews. Due to the sensitive nature of the subject matter, demographic data collected is not used, ensuring project participants' anonymity-something that was promised all participants.

For this pilot project, the data collection instrument was the person-centred interview, an exploratory, discussion-based method designed to "clarify the relations of individuality, both as output and input, to its sociocultural context" while eliciting behaviours and attitudes that suggest "hidden or latent dimensions of the organization of persons and of the sociocultural matrix and their interactions" (Levy and Hollan 1998, 334). The participant voices are needed to "tell the story" of Non-Status issues and concerns. Each interview lasted roughly forty to sixty minutes, and the participants' answers (i.e., to questions posed during the interview) were noted "in the moment" (pen and paper and/or typed into a word file). The interviews followed a general format whereby the researcher engaged each participant in a discussion while posing, in no precise order, a number of pre-determined questions designed to keep the interviewer attuned to the key themes being investigated while eliciting the participants' stories that, in this instance, provide insight into personal decision-making (Cortazzi 2001). As Ferrier has argued, "knowledge is constructed by people and groups of people; reality is multiperspectival; truth is grounded in everyday life and social relations; life is a text but thinking is an interpretative act; facts and values are inseparable; and science and all other human activities are value laden" (in Mitchell and Egudo 2003, 1).

Interviews were digitally recorded and transcribed. The research team then reviewed and finalized the coding process using NVivo10 software, which was followed by the production of a thematic analysis central to the characteristics and meaning of NonStatus Indian organizing. The coding process identified important comments or interview moments prior to proceeding with data interpretation (Boyatzis 1998). Encoding enabled the organization and categorization of data from which central themes were identified and developed (Fereday and Muir-Cochrane 2006). Data collection and analysis proceeded 
simultaneously, and transcripts were read and re-read to ensure accuracy and thematic applicability to the original data. One limitation of this approach is that it is mainly based on personal perceptions, which makes triangulating the perception of success, versus the actual issues associated with growing a Non-Status, representative political organization, difficult without observing directly or evaluating Aboriginal political growth vis-à-vis institutional networks. Additional issues-such as how social, religious, and cultural backgrounds influence perceptions about political saliency and progress, which necessarily introduces bias in perceptions and attitudes; and how the First Nations nationalist and sovereignty discourses that situate Non-Status political organizations as at once part of, and yet in competition, with Status Indian organizations and, as such, competing for a restricted funding pool-are not dealt with in this article, due to the scope and nature of these discussions. Each demands a separate treatment, and reflects courses of study the authors suggest demand greater academic attention.

\section{Key Challenges Confronting Non-Status Indians}

Each participant identified the legal/policy segregation that distinguishes Status Indians from Non-Status Indians as a key issue, which is most evident in the federal government's funding formulas that privilege Status Indian organizations. The respondents noted that Canada has imposed and given meaning to the term "Non-Status" through mechanisms such as the Indian Act, and that these categories did not exist prior to the imposition of colonial legislation. For instance, whereas the legal term is agreed upon by some (e.g., a Non-Status Indian is the child or grandchild of a Status Indian who is Indian by birth, but not recognized by the federal government as being entitled to federal registration), others consider it problematic and flawed, due to an insistence upon defining someone as an individual who is lacking "something." This reflects Peters' (1996) concern with the popular tendency to categorize Aboriginal urbanization as a social problem, and resonates with what Newhouse and Fitzmaurice (2012, xvi) describe as the "study of lack" when interpreting urban Aboriginal disparity. Consequently, we are left to try and understand urban Aboriginal and, central to this study, Non-Status Indian issues according what Ponting and Voyageur $(2001,75)$ define as the deficit paradigm. This situation dates to early Canadian beliefs in the perceived incommensurability of First Nations individuals and the off-reserve environment (Belanger 2013). The respondents suggested, however, that the situation is less historical but, rather, more attributable to Canada's ongoing attempts at conquering and dividing the nation's First Peoples. One respondent articulated the primary issues expressed by all participants: "What the Indian Act did was they severed that relationship and tied identity to blood and blood to benefit. As soon as they did that people don't think about their connections and relationships to everything that makes them Indigenous, they think about what they can get."

This legal/policy isolation has led to deep rifts developing between community members who may fall on either side of the Status-Non-Status divide. "People are told there is no money there for you," who then ask "where do we fit, we are in limbo, [as] we 
don't belong anywhere." Several examples offered indicated that this is more than a general community issue, and often penetrates immediate family concerns. For example, in several instances, two or three family members were identified as receiving program benefits to the exclusion of several other family members (this occurs both on- and off-reserve). As a respondent concluded, "The biggest hurdle to get over is inclusion and identity because we know who we are, but government(s) are not recognizing us as such and if they are they are not including us in the process that other aboriginal peoples are included." One organizational leader suggested that the Status-Non-Status issue is a minor concern and that the individual disconnection from community and cultures is attributable to policyinduced historical trauma, which Maria Brave Heart (2003) defined as the "cumulative and collective psychological and emotional injury sustained over a lifetime and across generations resulting from massive group trauma experiences" (also 1995, 1998, 1999, 2000).

Historical trauma theory, as defined by Brave Heart, suggests that deliberately inflicted trauma continues to impact a community's political, social, and economic core. The slow infiltration of foreign ideologies, both compelled and voluntary, led to a process evident in how subsequent generations refused to adhere to what colonial (and later, state) officials identified as contaminated traditions. This process of internalization over time emerged as a normative order, resulting in old ways being shunned in lieu of adopting foreign ways of acting and thinking. In a perverse twist, over time community members often adopted the once despised colonial critiques that centered out savage practice for alteration as legitimate appraisals of how to right community-based cultural wrongs. In this case, the issue remains one of policy/legal separation, albeit framed more circumspectly than the participants. As one respondent stated,

I continue to see and hear issues about [how] Non-Status people, especially urban Non-Status peoples, have all of these issues that Status wouldn't have, and I haven't seen it. I have seen it politicized by Aboriginal people and by government, I have seen it become an issue because people want funding and a political base, but when it comes down to human and needs and services and culture and identity and the issues that are directly related to their historic trauma and their choices of health and wellness I don't see any difference.

Either way, the effects are tangible. The cultural teachings and languages that individuals are disconnected from put them at a cultural disadvantage due to state-based identity markers. Access to traditional teachings and language was identified as an absolute priority, thus enabling individuals to restore old, or develop new, identities.

Interestingly, having and retaining Status is considered an important identity marker for some, and many of the participants acknowledged that this legal/policy separation has shaped countless identity (and other) issues for Non-Status individuals. A general trend has unfolded whereby Non-Status Indians are legally and socially excluded from First Nations communities. At the same time, they do not fit well within non-Aboriginal society. Exacerbating this separation are conventional provincial programs accessible to Non-Status Indians that frequently lack cultural relevance. 
Most respondents also identified the federal government's failure to formally recognize Non-Status Indians in terms of policy or as central constitutional players as a key concern. One respondent concluded, "The matter of getting the recognition and recognition comes with the benefits of being treated equitably and equally as Aboriginal peoples. We want to be recognized as people with constitutional rights as being the first peoples of this land." Many First Nations nationally equate band membership with Indian status, and a majority of Non-Status peoples are not band members. As such, they often do not have a right to live in their community (e.g., occupy a house, use band resources), are restricted from participating in the political process, and have no participatory rights (e.g., treaty or land claim negotiations). The absent right to live within a Status Indian community also tends to hinder access to Elders and language speakers from one's community. One respondent contends that this ruptures operational clan systems, thus detaching individuals from their teachings $v i s-\grave{a}$-vis the imposition of a foreign political system.

Outside of First Nations communities, Non-Status Indians exist as individuals and Canadian citizens with participatory rights to vote in federal, provincial, and municipal elections, while simultaneously lacking the legal recognition as Indians, an inability to claim specific Aboriginal rights, or to make an argument for a distinct culture and identity. Non-Status communities have difficulty obtaining standing within the Aboriginal political landscape. Only recently have they been formally recognized by the federal government, albeit somewhat reluctantly. Personal identity, shaped by a century-long struggle with the state and the Indian Act, as well as internal ideas about culture and community membership and a sense of belonging and purpose has become complex (Palmater 2011). For those living away from or outside the established and recognized political communities, such as Indian reserves, the need to secure political recognition is paramount from programmatic and political perspectives. Political recognition can, potentially, bring resources, and is therefore fundamentally linked to economics, according to one participant: "Economically, Status Indians have access to federal programs and services via their registration, in addition to access to traditional lands and resources either through Aboriginal rights, Treaty rights or agreements signed by your home community; and specific tax benefits." The provincial government, however, has failed to acknowledge Aboriginal ownership of natural resources, which means, to one participant, that reserve populations receive "most of the funding for programs and services, so we are forced to access mainstream programs and services which statistically [many] Aboriginal people do not [access] because of racism. They avoid the process altogether." It is more than simply being able to live one's life on reserve, however; rather, it's having access to reserve and other traditional lands for the purposes of hunting, fishing, and participating in other industries. From a programmatic point of view, to remain Non-Status impacts non-insured health benefits and wellness programs, and access to education and economic development programs. The distinction between Status and Non-Status Indians creates inequities in access to state resources-resources that could be used to improve quality of life. 


\section{Organizational Goals and Mandates}

In each case, the project participants purposely organized to address one or more of the aforementioned challenges to improve Non-Status political, economic, and social development. Generally speaking, the leaders of each organization envisioned their assembly becoming the political voice for regional off-reserve Aboriginal people and improving their constituents' quality of life through two primary avenues of advocacy: improved service delivery; and by convincing federal officials of the need to alter existing policies to improve access, thereby elevating Non-Status Indians to a policy level analogous that of Status Indians and facilitating improved political and economic participation in local and regional life. For instance, one organizational representative replied that they operated "basically to try and better Non-Status [Indians] and try and bring recognition to the NonStatus," whereas another offered a much more comprehensive take on their organization's purpose: "To ensure that we provide an organization for off-reserve Aboriginal Peoples in [their region] for the purpose of advancing their culture, tradition, economic and living conditions, we advocate for implementation of our treaty and Aboriginal rights, our land claims in the province, we work with all levels of government and industry to improve social, education, employment opportunities for Aboriginal peoples in the province." They added that the eventual goal "is to foster and strengthen cultural identity and pride in the Aboriginal population in the province, to inform the general public of our Aboriginal and treaty rights and in order to achieve full participation social, economic and political life of the province and we also work with all other Aboriginal organizations who aims and objectives are similar to ours."

Improving service delivery for populations lacking formal political representation that are apprehensive in engaging the mainstream system was each organization's foundational principle. In sum, each sought to establish equality and equity of Aboriginal programs, services, and other entitlements. This in turn led some organizations to establish broad mandates. For example, one group is working toward the betterment of urban Aboriginal people through the creation of programs and services that are self-determined by Aboriginal people, run by Aboriginal people, and exclusively for Aboriginal people. Other mandates encourage working "to support Aboriginal community organizations who offer programs and services in health, employment, recreation, mental health, language, and community events." All project participants indicated that their organizations are "colour blind," and that membership is not exclusive to Non-Status Indians. Other organizations were more political in nature, and were presented as a "political voice for the off-reserve Aboriginal people that reside in the province regardless of status or residency," while ensuring "that section 35 rights holders' rights are protected and make sure we have appropriate programs and services for those people we represent." Similarly, another organization advocates "on behalf of off-reserve Aboriginal peoples, Status or Non Status, Métis, and Inuit." Notably, most organizational representatives highlighted the Status-Non-Status divide as the basis of kinship and community-based social fractures, while also curiously indicating that it minimally influences their operations. One organization says that it seeks to acquire 
"Aboriginal treaty rights and human rights for off reserve Aboriginal peoples. Just because we are not on reserve or Non-Status does not mean that we are not beneficiaries to our treaties."

It is clear that the list of goals driving each organization's operations is significant and includes improving programming, funding for identity programs, ensuring Canada honours its fiduciary obligation to Non-Status Indians, securing Aboriginal rights, strengthening culture and treaty connections, improving economic development opportunities, pursuing healing and reconciliation with federal officials, pursuing self-government and augmented powers of self-determination, securing a land base, and seeking funding for language programs, just to name a few. Accordingly, each organization responds to how the federal government frames its role in relation to Non-Status Indians and to the availability of provincial resources and political dynamics of their immediate host community (i.e., reserve, municipality, province, territory). Funding affects political efficacy: some organizations have core funding and the organizational capacity needed to seek alternative funding arrangements; however, most do not. The majority receive minimal operational funds from federal (e.g., AANDC, Health Canada) and provincial agencies (e.g., provincial and territorial governments, municipal councils). They supplement these budgets by procuring service-delivery contracts through fund raising. But limited funding opportunities means many organizations must work with (or guide their members to) mainstream programs and service providers; or, that their organizations are overlooked for funding because as a Non-Status organizations they are "an after-thought to the process."

\section{Political Alliances}

Due to the media's focus on AFN activities, to name one influential group, the Canadian public has been preconditioned to believe that Aboriginal peoples interact almost exclusively with federal government officials and, to a much lesser extent, provincial officials. Further to this, there is a belief that historic political animosities between peoples and their political organizations result in limited interface and ineffective partnerships. Finally, colonialism has been presented as ubiquitous and ongoing (i.e., post-colonialism, systemic racism), which is an impenetrable barrier to fruitful Aboriginal-non-Aboriginal partnerships. The project participants were quick to dispel these beliefs and demonstrated a wide diversity of political and economic relationships with a broad array of players. Some groups have been operational longer and, as a result, have developed and fostered extended networks in relation to some of the younger organizations, which admittedly have limited political reach.

Federal funding, or more accurately the lack thereof, also has an impact on the nature and extent of extra-organizational relationships with the public and private sector, and consequently demands administrative creativity to ensure ongoing operations. One organization involved in this study works with the private sector (i.e., oil companies, municipal business leaders), both the federal and provincial governments, First Nations, Aboriginal, and non-Aboriginal non-profit organizations, cultural groups such as the 
Muslim Association and the African Council, tourism officials, educators, and academicsin sum, anyone interested in improving their understanding of Aboriginal peoples and how to provide improved services. Another organization has forged close relationships with the RCMP, the Salvation Army, social services, education, hospitals, and shelters, the goal being to facilitate positive local outcomes while conducting referrals and engaging in case management with other organizations. Some organizations insist on working with what they describe as other Status/colour-blind groups, whereas others tend to work solely with high-profile organizations.

\section{Federal Government in Addressing Non-Status Issues}

All respondents called for Aboriginal peoples to ignore the Status Indian legal category, particularly as it relates to accessing federal funding for service delivery. One respondent put it this way:

I think both levels, all levels of government play a significant role in addressing those needs. I think the jurisdictional debate that generally occurs regarding Status or Non-Status people is a debate that loses, that distracts people from addressing the real needs of people on the ground. So I think that the federal government has a significant role to play in this by how it constructs its programs and services and interacts because we have to realize that First Nations people who live on reserves, or Métis who live on settlements or land claim areas, the great majority of those people don't live there, they actually live and participate in the urban economic life of cities and we understand this because the statistics tell us and this has been going on for decades. This is not a new phenomenon by any stretch of the imagination. But it provides you with challenges for services and for the federal government, if you have First Nations peoples who are the jurisdictional responsibility of the federal government, on reserve primarily living off-reserve then I think there needs to be a harmonization between the provinces and the federal government to address those needs. It's in all of our interests to do that.

Some recognized that First Nations have roles to play in fixing the Non-Status/Status issue. One respondent related to how band membership codes can be developed in ways that can exclude Non-Status Indians: "The challenges that I see for Non-Status Indians as I see them will be whether or not their home communities or nations are going to deal with Non-Status Indians," whether "they [are] going to amend their membership codes to deal with Non-Status Indians or are they going to leave Indian status provisions to deal with the issue." Another noted, "[ $\mathrm{t}$ ]his is a key issue, and many First Nations are beginning to recognize this as their children and grandchildren may not be entitled to registration and as a result may not be entitled to live on reserve. But even more serious, this issue is about the future of First Nations communities because if the numbers of Non-Status Indians grow there won't be communities, so it has a very real impact for communities." The way forward, then, is to have government recognize Indigenous nations inherent rights to be 
self-determining: "Canada can decide their half of the treaty partner, and we [Indigenous nations] can decide our half of the treaty partner that is at a very simple go forward level in the medium and long term."

\section{Discussion}

The interviews reveal a complexity of issues confronting Non-Status Indians and the real effects of government policy upon their lives, from both historic and contemporary perspectives. It is clear that Non-Status Indians, as a legal category of Indians, were pushed aside or abandoned by Status Indian and Métis organizations following the federal government's lead in this regard during the last two decades. The 1985 creation of the Federal Interlocutor for Métis and Non-Status Indians was intended to "strengthen relationships with Métis, Non-Status Indians and urban Aboriginal people to raise awareness of their needs, improve access to federal services ... ." It is perplexing that none of the respondents mentioned this office during their interviews, despite almost two decades of existence. In response to the abandonment, and perhaps to the failure of the Federal Interlocutor, NonStatus Indian political organizations were formed to provide their own voice in federal and provincial politics and to push for policy inclusion.

The organizational leaders we spoke with discussed advocating for corresponding access to services for all Aboriginal peoples, whereas the urban organizations advocated for equitable funding for urban programs and services based on demographics (i.e., over half of the Aboriginal population lives in urban areas; therefore, over half of Aboriginal funding should be directed accordingly). Many spoke of the importance and need to heal, restore, and strengthen community members' Aboriginal identities by returning to traditional Aboriginal cultures, languages, and traditions. There was also a strong desire to prevent state definitions of Indian Status from further dividing Aboriginal communities and watering down political efforts. Yet the very reason for these organizations' existence is that Status issues generate the greatest government response. The Indian Act was identified as the source of community and kinship fractures, and that the Status-Non-Status divide is a real social concern, but organizations made efforts to ensure that they were minimally influenced by these forces. Take, for example, the following response:

To my knowledge in our organization there is no difference. There is no policy distinction for us, there is no program definition around that, anyone who selfidentifies as having Aboriginal or First Nations, they all get the same services, the same access to services from us and I don't know that they have different challenges. I think that the issue gets down to people who are connected to their culture to their family and their community and a community is defined in so many different ways so the community factor may be an issue for people if they look at a land base as the only thing they call community. For me the issue around connection to their cultural roots and their families becomes the bigger issue and the bigger challenge for government and for everyone and that is for any person of Aboriginal decent who is disconnected because of the historic trauma that has occurred as a result of 
government policy and Aboriginal people are disenfranchised and disadvantaged because they have been disconnected with the teachings that would make them healthy and whole.

This study has demonstrated that Non-Status Indians are beginning to emerge from the political periphery by creating new political organizations to respond to their own distinct needs. In as much as this work has improved our understanding of this nascent phenomenon, it also raises a series of important questions: Are these organizations representatives of what might be described as a new political assembly of Aboriginal people? What are the political goals of these groups? How do they see themselves in relation to other Aboriginal groups? Who are the members of these new groups? One issue that surfaced in this research that demands additional attention is the emergence of the NonStatus First Nation Band, a new and controversial entity that seeks to bridge the old and the new while ensuring continuity of identity and access to government programs and funding. It particularly fosters the creation of a positive, self-generated Aboriginal identity out of what was a previously marginalized group, and has been effective in securing recognition and acknowledgement from federal and provincial governments, albeit not from existing First Nations organizations. All told, these new entities create a sense of inclusion and community necessary for identity development and maintenance by providing individuals with a mechanism for establishing Aboriginal identity: a group that one can become a part of that reciprocates by stating that you belong to them.

Fixing the problems that have arisen from the imposition of Indian Status upon the Aboriginal population is not easy. The creation of Status may have been a means of creating a legible landscape by setting out the rules for determining who is and not an Indian for public policy purposes, but these rules were destined for decommission once Indians vanished (or the rules were created to disband Indian communities, thereby resulting in their disuse). No thought was given to a future where Status and Non-Status Indians would potentially be competing for access to resources. Or how communities would operate according to rules that created insiders and outsiders. Or, perhaps most importantly, how a group of people separated from kinship networks by extra-community legislation was expected to respond to being abandoned by Status Indian and Métis organizations, and the federal government.

Organizations such as CAP and Non-Status First Nations highlight the Non-Status desire for inclusion and political recognition. The landscape, while still legible, has become more complex and difficult to navigate. It is hard to ignore 133,000 Non-Status Indians, either as individuals or as a series of political communities. In one case, a project participant indicated that fixing the problem is not that difficult considering that "when you have nice definitions and packages" defining "who receives services" it simplifies the process of creating an inclusive model. The desire for legibility however has created the current complex identity and policy situation. 


\section{Conclusion}

The re-emergence of Non-Status Indians into the Aboriginal political landscape through a new set of organizations creates a policy dilemma around recognition and rights. The questions posed by Forte (2013) in Who is an Indian? linger, despite a century and half of state attempts to "disappear" Indians. Scott (1998) contends that political states attempt to create legible populations in order to more easily administer populations. This is readily evident in Canada as it relates to Indians. Specifically, the legal categories of Status and NonStatus Indian were created to manage those Indians in need of civilization (Status Indians) by developing appropriate programs. Those who had assimilated into Canadian society lost their status as Indians and as such no longer required programs. What Canadian officials did not count on was the resilience of Aboriginal people in general, or that Non-Status Indians in various regions nationally would create political organizations to advocate on behalf of their unique needs. This article has scratched the surface by highlighting that Non-Status Indians are unwilling to carry on accepting their status as abandoned, and are engaging in the creation of new political communities to advance their interests. We would contend that Canada's attempt to create a landscape of legible populations has backfired. Three key themes emerged from the participant dialogues: (1) the legal/policy segregation of Non-Status Indians from other Aboriginal peoples; (2) the lack of political recognition of Non-Status Indians; and (3) the lack of access to social and economic resources. The three key themes embrace a wealth of concerns that demand further unpacking to truly uncover the nature of the issues affecting Non-Status Indians in Canada. They do, however, provide us with a baseline of issues from which to evaluate the reasons related to each organization's emergence that allows us to speak more concretely as to whether or not we are currently witnessing the evolution of a new national political community. ${ }^{8}$ In our minds, it is clear that a new political community of Non-Status Indians with distinct goals and objectives and institutions is starting to emerge in several places across the country, and is asking that Canada address its needs as part of a post-colonial public policy agenda.

8 Amplifying the resolve to prevent disappearance is a January 2013 Federal Court of Canada decision that challenged Canada's policy orientation. It found that Métis peoples and Non-Status Aboriginal peoples are to be considered Indians under section 91(24) of the Constitution Act, 1867. Justice Michael Phelan noted that Non-Status Indians are considered to be constitutionally considered "Indians," and that the Non-Status category was "effectively created by the federal government in the first place, as a result of years of legislation that sought to define who was considered an 'Indian"' (Daniels v. Canada 2013). While it is too early to speculate on what the practical effect of this decision will be, it signalled the court's unwillingness to allow the government to continually ignore Non-Status Indians. On 6 February 2013, the Government of Canada appealed the ruling. There has yet to be a ruling on the appeal. 


\section{Bibliography}

Alfred, T. 2009. Peace Power and Righteousness: An Indigenous Manifesto. 2nd ed. Don Mills, ON: Oxford University Press.

Belanger, Y. D. 2013. "Breaching Reserve Boundaries: Canada v. Misquadis and the Legal Evolution of the Urban Aboriginal Community." In Indigenous in the City: Contemporary Identities and Cultural Innovation, eds. E. Peters and C. Andersen, 69-87. Vancouver: UBC Press.

- - - 2006. "Seeking a Seat at the Table: A Brief History of Indian Political Organizing in Canada, 1870-1951.” Ph.D. diss., Peterborough, ON: Trent University.

Belanger, Y. D., K. Fitzmaurice, and D. R. Newhouse. 2008. "Creating a Seat at the Table: A Retrospective Study of Aboriginal Programming at Canadian Heritage." Canadian Journal of Native Studies 28 (1): 33-70.

Boyatzis, R.E. 1998. Thematic Analysis: Coding as a Process of Transforming Qualitative Information. Thousand Oaks, CA: Sage.

Brave Heart, M. 2003. "The Historical Trauma Response Among Natives and its Relationship with Substance Abuse: A Lakota illustration.” Journal of Psychoactive Drugs 35: 7-13. http://dx.doi.org/10.1080/02791072.2003.10399988.

-__—. 2000. "Wakiksuyapi: Carrying the Historical Trauma of the Lakota." Tulane Studies in Social Welfare 21-22: 245-66.

-_-. 1999. "Oyate Ptayela: Rebuilding the Lakota Nation Through Addressing Historical Trauma among Lakota Parents." Journal of Human Behavior in the Social Environment 2 (1-2): 109-26. http://dx.doi.org/10.1300/j137v02n01_08.

- - - 1998. "The Return to the Sacred Path: Healing the Historical Trauma Response among the Lakota." Smith College Studies in Social Work 68 (3): 287-305. http:// dx.doi.org/10.1080/00377319809517532.

_- - 1995. "The Return to the Sacred Path: Healing from Historical Trauma and Historical Unresolved Grief Among the Lakota." Ph.D. diss., Smith College.

Canada. 2009. Aboriginal Peoples in Canada: Inuit, Métis and First Nations, 2006 Census. Statistics Canada. Ottawa.

- - - 1996. For Seven Generations: An Information Legacy of the Royal Commission on Aboriginal Peoples [CD-ROM]. Ottawa: Canada Communications Group.

Chapman, I., D. Newhouse, and D. McCaskill. 1991. "Management in Contemporary

Aboriginal Organizations." Canadian Journal of Native Studies 11 (2): 333-49.

Cortazzi, M. 2001. "Narrative Analysis in Ethnography." In Handbook of Ethnography, ed. Paul Atkinson, 384-94. London: Sage.

Daniels v. Canada [2013] F.C.R. 6.

Dockstator, M. 2001. Toward an Understanding of the Crown's Views on Justice at the Time of Entering Into Treaty with the First Nations of Canada. Saskatoon: Office of the Treaty Commissioner.

Fereday, J., \& Muir-Cochrane, E. 2006. "Demonstrating Rigor Using Thematic Analysis: A Hybrid Approach of Inductive and Deductive Coding and Theme Development." International Journal of Qualitative Methods 5 (1): 1-11. 
Forte, M. (Ed). 2013. Who Is an Indian? Race, Place and the Politics of Indigeneity in the Americas. Toronto: University of Toronto Press.

Galois, R.M. 1992. "The Indian Rights Association, Native Protest Activity and the "Land Question” in British Columbia, 1903-1916." Native Studies Review 8 (2): 1-34.

Ignatieff, M. 2000. The Rights Revolution. Toronto: House of Anansi Press.

Kulchyski, P. 1988. “'A Considerable Unrest': F.O. Loft and the League of Indians.” Native Studies Review 4 (1-2): 95-117.

- - - 1993. "Anthropology in the Service of the State: Diamond Jenness and Canadian Indian Policy." Journal of Canadian Studies 28 (2): 21-50.

Ladner, K. L. 2003. "Rethinking the Past, Present and Future of Aboriginal Governance." In Reinventing Canada, ed. Janine Brodie and Linda Trimble, 43-60. Toronto: Canadian Scholars Press.

Lawrence, B. 2004. "Real" Indians and Others: Mixed-Blood Urban Native Peoples and Indigenous Nationhood. Lincoln: University of Nebraska Press.

Leslie, J. 1999. "Assimilation, Integration, or Termination? The Development of Canadian Indian Policy, 1943-1963.” Ph.D. diss., Carleton University.

Leslie, J. and R. Maguire. 1978. The Historical Development of the Indian Act, 2nd ed. Ottawa: Indian and Northern Affairs Canada.

Levy, R., and D. Hollan. 1998. "Person-Centered Interviewing and Observation." In Handbook of Methods in Cultural Anthropology, ed. H. Russell Bernard, 333-64. Walnut Creek, CA: Altamira.

Manuel, G. and M. Posluns. 1974. The Fourth World: An Indian Reality. Toronto: CoIlier Macmillan Canada Ltd.

McFarlane, P. 1993. Brotherhood to Nationhood: George Manuel and the Making of the Modern Indian Movement. Toronto: Between The Lines.

Miller, J.R. 1991. Skyscrapers Hide the Heavens: A History of Indian-White Relations in Canada. Toronto: University of Toronto Press.

Newhouse, D. 2003. "The Invisible Infrastructure: Urban Aboriginal Institutions and Organizations." In Not Strangers in These Parts: Urban Aboriginal Peoples, ed. D. Newhouse and E. Peters, 243-53. Ottawa: Policy Research Initiative.

Newhouse, D. and Y. Belanger. 2010. “'Beyond the "Indian Problem': Aboriginal Peoples and the Transformation of Canada." In The Oxford Handbook of Canadian Politics, ed. J. C. Courtney and D. E. Smith, 339-61. New York: Oxford University Press.

Newhouse, D. and K. FitzMaurice. 2012. "Introduction." In Well-being in the Urban Aboriginal Community: Fostering Biimaadiziwin, a National Research Conference on Urban Aboriginal Peoples, ed. D. Newhouse, K. FitzMaurice, T. McGuire-Adams, and D. Jetté, ix-xxi. Toronto: Thompson Educational Publishing.

Ontario Coalition of Aboriginal People, By-Laws, 25 October 2008.

Palmater, P. 2011. Beyond Blood: Rethinking Indigenous Identity. Saskatoon: Purich Publishing Ltd.

- - - 2013. Indigenous Nationhood (blog). http://indigenousnationhood.blogspot.ca.

Patterson, E. P. 1962. "Andrew Paull and the Canadian Indian Resurgence." Ph. D. diss., Seattle: University of Washington. 
_-_. 1978. "Andrew Paull and the Early History of British Columbia Indian Organizations." In "One Century Later": Western Canadian Reserve Indians Since Treaty 7, ed. I. A.L. Getty and D. B. Smith, 43-54. Vancouver: UBC Press.

Peters, E. 1996. "Urban” and "Aboriginal": An Impossible Contradiction?" In City Lives and City Forms: Critical Research and Canadian Urbanism, ed. J. Caulfield and L. Peake, 47-62. Toronto: University of Toronto Press. http://dx.doi.org/10.2747/02723638.30.6.652.

Peters, E. and V. Robillard. 2009. “Everything you want is there': The Place of the Reserve In First Nations' Homeless Mobility." Urban Geography 30 (6): 652-80.

Ponting, J. R., and R. Gibbons. 1980. Out of Irrelevance: A Socio-political Introduction to Indian Affairs in Canada. Toronto: Butterworths.

Ponting, R. J. and C. Voyageur. 2001. "Challenging the Deficit Paradigm: Grounds of Optimism Among First Nations in Canada." Canadian Journal of Native Studies 21 (2): 275-307.

Sawchuk, J. 1995. "Fragmentation and Realignment: The Continuing Cycle of Métis and Non-Status Indian Political Organizations in Canada." Native Studies Review 10 (2): 77-95.

- - - 1998. The Dynamics of Native Politics: The Alberta Métis Experience. Saskatoon: Purich Publishing.

- - - 2003. “The 'Metis Indians' of Ontario." Eelectica, August. http://www.ecclectica.ca/ issues/2003/2/sawchuk.asp.

_-_. 2008. "Indians in Contemporary Society." In Handbook of North American Indians, vol. 2: Indians in Contemporary Society, eds. Bailey, Garrick A. and W. Sturtevant, 294-301. Washington, D.C: Smithsonian Institution.

Scott, J. 1998. Seeing Like a State: How Certain Schemes to Improve the Human Conditions Have Failed. New Haven: Yale University Press.

Shewell, H. 2004. "Enough to Keep Them Alive": Indian Welfare in Canada, 1873-1965. Toronto, University of Toronto Press.

Shields, N. D. 2001. "Anishinabek Political Alliance in the Post-Confederation Period." M.A. thesis. Kingston, ON: Queen's University.

Taylor, C. 1994. “The Politics of Recognition.” In Multiculturalism: Examining the Politics of Recognition, ed. Amy Gutmann, 25-73. Princeton: Princeton University Press.

Titley, E. B. 1986. A Narrow Vision: Duncan Campbell Scott and the Administration of Indian Affairs in Canada. Vancouver: UBC Press.

_-_. 1983. "W.M. Graham: Indian Agent Extraordinaire." Prairie Forum 8 (1): 25-41.

Tully, J. 1995. Strange Multiplicity: Constitutionalism in an Age of Diversity. New York: Cambridge University Press.

Waldron, J. 2000. "Cultural Identity and Civic Responsibility." In Citizenship in Diverse Societies, ed. Will Kymlicka and Wayne Norman, 155-74. Don Mills: Oxford University Press, 2000.

Wilson, B. 1985. “Aboriginal Rights: A Non-Status Indian View." In The Quest For Justice: Aboriginal People and Aboriginal Rights, ed. M. Boldt and J. A. Long, 62-68. Toronto: University of Toronto Press. 